\title{
WITHIN-IN FLUME SEDIMENT DEPOSITION IN A FORESTED CATCHMENT FOLLOWING WILDFIRE AND POST-FIRE BENCH TERRACING, NORTH-CENTRAL PORTUGAL
}

\author{
J.J. KEIZER*, M.A.S. MARTINS, S.A. PRATS, S.R. FARIA, \\ O. GONZÁLEZ-PELAYO, A.I. MACHADO, M.E. RIAL-RIVAS, L.F. SANTOS, \\ D. SERPA, M.E.T. VARELA
}

\begin{abstract}
Earth surface processes team, Centre for Environmental and Marine Studies (CESAM), Dept. Environment and Planning, University of Aveiro, 3810-193 Aveiro, Portugal.
\end{abstract}

\begin{abstract}
Wildfires increase plot-scale soil erosion rates across the world. However, very few studies have monitored post-fire erosion losses at the catchment scale, especially in the Mediterranean region. The FIRECNUTS project was originally set out to address this research gap by selecting a recently burnt catchment and instrumenting its outlet with two flumes with maximum discharge capacities of 120 and $1700 \mathrm{l} \mathrm{s}^{-1}$. Six months after the fire, however, this experimental catchment was bench terraced by bulldozer. Furthermore, the smallest flume suffered from regular deposition of sediments from the onset of its construction. This study was therefore an attempt to explore whether quantifying this deposition of sediments could provide further insight into the sediment yield of a recently burnt and terraced catchment. To this end, the deposited sediments were removed and weighted on a total of 101 occasions during a three year period. The results revealed that: (i) the amounts of sediment deposited over the three hydrological years corresponded to relatively small erosion rates, varying between 0.030 and $0.046 \mathrm{Mg} \mathrm{ha}^{-1} \mathrm{yr}^{-1}$; (ii) while bench terracing is generally viewed as a soil and water conservation technique, it did not produce a clear decrease in sediment deposition, as deposition per $\mathrm{mm}$ of streamflow was the same before and after terracing $\left(0.8 \mathrm{~kg} \mathrm{~mm}^{-1}\right)$; (iii) daily sediment deposition could be explained reasonably well by daily rainfall volume and maximum daily streamflow volume.
\end{abstract}

Sedimentación en el cauce de una cuenca forestal tras un incendio forestal y prácticas de aterrazamiento en el norte de Portugal

RESUMEN. Numerosos estudios llevados a cabo en todo el mundo han demostrado que los incendios forestales aumentan las tasas de erosión del suelo a escala de parcela. Sin embargo, muy pocos han monitorizado las pérdidas por erosión post-incendio a escala de cuenca, especialmente en la región mediterránea. Originalmente, el proyecto FIRECNUTS tenía como objetivo 
ampliar esta investigación, instrumentando una cuenca recientemente quemada con dos canales de flujo con capacidades máximas de 120 y $1700 \mathrm{l} \mathrm{s}^{-1}$. Sin embargo, la cuenca experimental fue aterrazada con un bulldozer seis meses después del incendio. Además, el canal más pequeño sufrió sedimentación desde el inicio de su construcción. Este estudio intentó determinar si la cuantificación de este depósito de sedimentos podría proporcionar información sobre la exportación de sedimentos de un área quemada que posteriormente fue aterrazada. Para este objetivo, se recogieron y pesaron los sedimentos depositados en 101 ocasiones a lo largo de tres años. Los resultados revelaron que: (i) las cantidades de sedimentos depositados durante los tres años hidrológicos fueron relativamente pequeñas, variando entre 0.030 y $0.046 \mathrm{Mg} \mathrm{ha}^{-1} \mathrm{a}^{-1}$; (ii) las terrazas, consideradas como una técnica de conservación de suelos y agua, no produjeron una clara disminución de la sedimentación, pues fue la misma antes y después del aterrazamiento (0.8 $\mathrm{kg} \mathrm{mm}^{-1}$ de caudal); (iii) la sedimentación diaria podría explicarse por el volumen de precipitación diaria y el volumen máximo del caudal diario.

Key words: sediment deposition, sediment yield, wildfire, bench terracing, Portugal.

Palabras clave: deposición de sedimentos, producción de sedimentos, incendio forestal, terrazas, Portugal.

*Corresponding author: Earth surface processes team, Centre for Environmental and Marine Studies (CESAM), Dept. Environment and Planning, University of Aveiro, 3810-193 Aveiro, Portugal. E-mail: jjkeizer@ua.pt

\section{Introduction}

In Portugal, like in other Mediterranean countries, wildfires have become an important concern from the point of view of civil protection, forest management, and environmental pollution. On average, wildfires have affected some 100000 ha of Portuguese rural lands per year since the 1980s, and future predictions do not suggest major changes in the next few decades (Pereira et al., 2006).

As reviewed by Cerdà and Bodí (2007), Shakesby (2011) and Bodí et al. (2012), wildfires have often been reported to lead to conspicuous increases in soil erosion rates in the Mediterranean Basin. Such increases have also been inferred for the two principal forest types in the present study region, i.e. mono-specific and mixed plantations of maritime pine, and eucalypt (e.g. Leighton-Boyce et al., 2007; Ferreira et al., 2008). Fireenhanced erosion rates are generally attributed to the partial removal of the protective vegetation and litter cover, combined with heating-induced alterations in soil properties 
such as soil water repellency (e.g. Cerdà, 1998; Cerdà and Doerr, 2008) and aggregate stability (e.g. Varela et al., 2010; Mataix-Solera et al., 2011). Nonetheless, there continue to be various important research gaps on fire effects on soil erosion, in part due to the rather limited number of studies (Shakesby, 2011). This is especially the case for the effects beyond the scale of plots.

To address the lack of post-fire erosion studies beyond the plot scale, the FIRECNUTS project selected and instrumented a catchment in north-central Portugal immediately after a wildfire. Less than six months later, however, the larger part of the catchment was bench terraced for the establishment of a new eucalypt plantation. Monitoring of the catchment was nonetheless continued, also because the effects of postfire management practices have received even less research attention than the effects of fire itself, at least in Portugal (Shakesby et al., 1996; Terry, 1996; Malvar et al., 2013; Martins et al., 2013; Prats et al., 2014a). Furthermore, while terraces are traditionally viewed as a technique for soil conservation (e.g. Morgan, 2005; Arnaéz et al., 2015), prior to this study the present authors had measured high rates of splash erosion on recent terraces (Fernández-Raga et al., 2010) and had regularly observed erosion features such as pedestals, collapsing terrace sides and rills on terraced hill slopes in the study region.

Almost as unforeseen as the bench terracing was that, basically from the onset of the catchment's installation, sediments started to be deposited in the upper of two flumes. Since these depositing sediment had to be removed anyway for the proper functioning of the station, the idea surged to study how the deposition of sediments would vary with time-sincefire (and, in this particular case, would differ between before and after bench terracing), how important it would be compared to the export of suspended sediments, how it would relate to plot-/slope-scale sediment losses, and how it would be linked to rainfall and streamflow. The present paper aimed to address the first and the fourth of these research questions.

\section{Materials and methods}

\subsection{Study area and catchment}

This study concerned a catchment of 28.8 ha near the hamlet of Ermida in the municipality of Sever do Vouga, north central Portugal (Fig. 1). The catchment was burnt by a wildfire that took place between the $26^{\text {th }}$ and $28^{\text {th }}$ of July 2010 and that affected in total almost 300 ha (DUDF, 2011). By the time of the fire, the catchment was mainly covered by plantations of eucalypt (Eucalyptus globulus Labill.) but also included a plantation of maritime pine (Pinus pinaster Ait.) and a stand of cork oak (Quercus suber L.). Overall, fire severity sensu Keely (2009) appeared to be moderate, in line with the assessment carried out at the two study sites of Martins et al. (2013) using tree crown scorching, litter consumption and ash colour as indicators (following Shakesby and Doerr (2006) and various prior studies in the region such as Malvar et al. $(2011,2013)$ and Prats et al. (2013, 2014b)). During the winter of 2010/11, the bulk of the eucalypt plantations and the pine plantation within the catchment were first logged and then bench terraced using a bulldozer (the terraces are clearly visible in Fig. 1), in preparation of the establishment of a new eucalypt plantation. The bench terracing was done following 
a reforestation plan that had been approved prior to the wildfire, so that it excluded the largest part of the maritime pine stand. The bench terracing started early March 2011 and took 2-3 weeks.

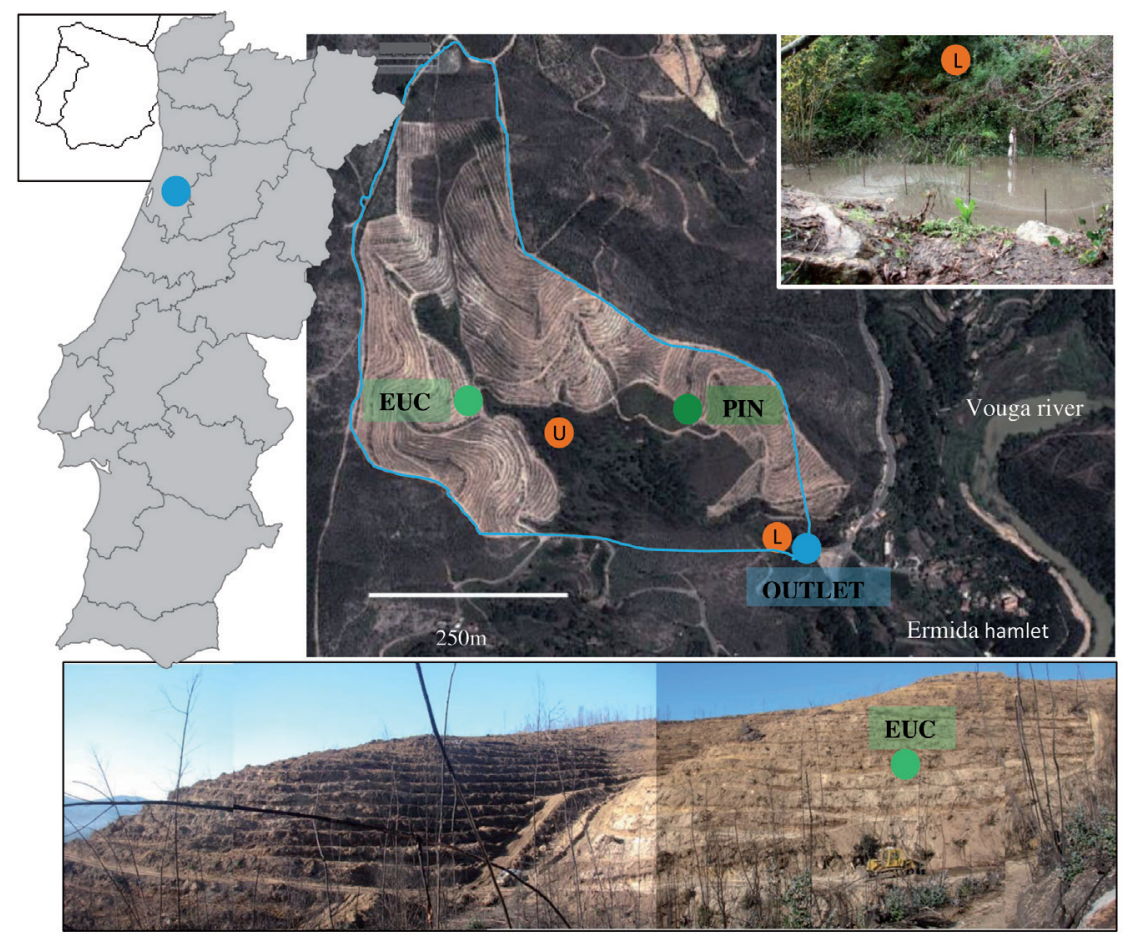

Figure 1. Location of the Ermida study catchment in north-central Portugal, of the catchment's outlet and boundaries as well as of the two study sites of Martins et al. (2013) (EUC, PIN) and of the upper and lower retention ponds $(U, L)$ within the catchment (right-hand baseline map: Google Earth, 2015). Also shown are pictures of the EUC site immediately after bench terracing (composite of two pictures taken sequentially) and of the lower retention pond at the end of a

rainfall event.

The climate of the study area can be classified as humid meso-thermal (Csb, according to the Köppen classification), with moderately dry but extended summers (DRA-Centro, 1998). The nearest weather and rainfall stations (Castelo Burgães: $40^{\circ}$

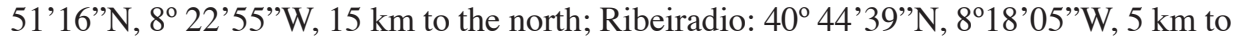
the east; SNIRH, 2011) had a long-term mean annual temperature of $14.9^{\circ} \mathrm{C}$ and a longterm mean annual rainfall of $1609 \mathrm{~mm}$. In terms of geology, the study area pertains to the major physiographic unit of the Hesperic Massif (Ferreira, 1978), which is mainly constituted of pre-Ordovician schists and greywackes but locally includes Hercynian granites. Likewise, the catchment consist mainly of schists but the eucalypt site studied by Martins et al. (2013) was on granite. According to the existing soil map (1: 1000 000; Cardoso et al., 1971, 1973), the soils in the study area are predominantly Humic 
Cambisols. However, the soils of the two study sites of Martins et al. (2013) were also described in the field and, before the bench terracing, ranged from Humic Leptosols to Humic Cambisols at the eucalypt site, and from Lithic Leptosols to Humic Leptosols at the pine site (WRB, 2006). The soil texture of the A-horizons was identified in the field as sandy loam at the eucalypt site and as sandy clay loam at the pine site.

\subsection{Data collection}

The outlet of the catchment was instrumented with a hydrometric station that consisted of two flumes, to avoid interfering with the local practice to diverge part of the streamflow during summer to an irrigation tank. The H-flume and the subsequent cutthroat flume had maximum discharge capacities of 120 and $1700 \mathrm{l} \mathrm{s}^{-1}$, respectively. The station was installed as soon as possible after site selection, and it was operational from 18 September 2010 onwards. By then, some $25 \mathrm{~mm}$ of rainfall had fallen but at relatively low intensities $\left(\mathrm{I} 30<10 \mathrm{~mm} \mathrm{~h}^{-1}\right)$. During this study, water level in the flumes was recorded at 2-min intervals and converted to discharge using the flumes' stage-discharge curves, adjusted to local conditions based on a series of manual stage-discharge measurements. The burnt area was furthermore equipped with four tipping-bucket rainfall gauges (Pronamic Professional Rain Gauge with $0.2 \mathrm{~mm}$ resolution) and several storage gauges (in-house design), installed next to the automatic gauges for the purpose of verifying their results.

During the first field trip after the entering in function of the hydrometric station on 4 October 2010, the authors noted the deposition of some sediment in the H-flume but just removed them by stirring them up. From then onwards, however, the deposited sediments were weighted during each field trip ("read-out"). The sediments were first weighted in the field and then in the laboratory, by drying sub-samples at $105^{\circ} \mathrm{C}$ during 24 h (APHA, 1998). Furthermore, the sediment samples collected during the first 63 read-outs (till 11 April 2012) were sieved manually into 8 different fractions $(<50 \mu \mathrm{m}$; $50 \mu \mathrm{m}-<200 \mu \mathrm{m} ; 200 \mu \mathrm{m}-<1 \mathrm{~mm} ; 1-<2 \mathrm{~mm} ; 2 \mathrm{~mm}-<3.15 \mathrm{~mm} ; 3.15-<4 \mathrm{~mm}$; $4 \mathrm{~mm}-<5 \mathrm{~mm} ; \geq 5 \mathrm{~mm}$ ), while those collected during the first 67 read-outs (till 9 May 2012) were analysed for the organic matter content of the $<2 \mathrm{~mm}$ fraction using the loss-on-ignition method $\left(4 \mathrm{~h}\right.$ at $\left.550^{\circ} \mathrm{C}\right)$. In total, the deposited sediments were collected during 101 read-outs covering the first three hydrological years after the wildfire, starting 5 October 2010 and ending 3 October 2013. The bulk of the read-outs involved intervals of 1 week (54\%) or 2 weeks (35\%), while logistic difficulties constrained the intervals of the last two read-outs (comprising 6 and 9 weeks, respectively).

\subsection{Data analysis}

Since the read-outs involved periods of varying lengths, data analysis focussed on daily figures. Daily figures of rainfall, streamflow and deposited sediments were computed by dividing the cumulative values over the read-out periods by their lengths of days. In addition, rainfall and streamflow were quantified in terms of maximum values over the read-out periods, i.e. as the maximum rainfall intensity over any period of $30 \mathrm{~min}$ (I30) and as the maximum of the daily streamflow values. 
The temporal patterns in daily sediment deposition were assessed for their randomness by means of the runs above and below the median test (Sokal and Rohlf, 1981), testing against the $\mathrm{Z}$ statistic. This was done for different parts of the study period. Furthermore, Pearson's product-moment correlation coefficient (r) was computed to explore the relation of daily sediment deposition with daily and maximum rainfall and streamflow volumes, both for the entire study period as for the individual hydrological years. The coefficients were obtained and tested with STATISTICA for Windows Version 9.0 by StatSoft Inc.

\section{Results}

\subsection{Annual rainfall, streamflow and sediment deposition}

The three hydrological years following the wildfire differed markedly in rainfall volumes (Table 1). While the first year corresponded to an about average year (circa 10\% less rainfall than the long-term average), the second and third years were some $30 \%$ drier and wetter, respectively, than on average, and differed in almost $1000 \mathrm{~mm}$ of rainfall.

The three hydrological years also revealed a clear contrast in streamflow volumes (Table 1). Whereas the first and third year produced very similar streamflow volumes (4.2$4.3 \mathrm{~mm} \mathrm{day}^{-1}$ ), the second year produced almost $40 \%$ less. The annual runoff coefficients were unrelated to rainfall volumes; instead, they decreased with increasing time-since-fire and most markedly between the first and second year (from 1.10 to 0.81 to 0.75 ).

Table 1. Total rainfall, streamflow and within-flume sediment deposition in a forest catchment during the first three hydrological years following a wildfire.

\begin{tabular}{|c|c|c|c|c|c|}
\hline $\begin{array}{c}\text { Hydrological } \\
\text { year }\end{array}$ & $\begin{array}{c}\text { Start date } \\
(\mathbf{d d}-\mathbf{m m})\end{array}$ & $\begin{array}{c}\text { Number } \\
\text { of days }\end{array}$ & $\begin{array}{c}\text { Rainfall } \\
(\mathbf{m m})\end{array}$ & $\begin{array}{c}\text { Streamflow } \\
(\mathbf{m m})\end{array}$ & $\begin{array}{c}\text { Deposited sediments } \\
(\mathbf{k g})\end{array}$ \\
\hline $2010 / 11$ & $05-10$ & 366 & 1401 & 1541 & 1077 \\
\hline $2011 / 12$ & $06-11$ & 357 & 1161 & 936 & 1322 \\
\hline $2012 / 13$ & $27-09$ & 372 & 2126 & 1599 & 869 \\
\hline
\end{tabular}

The three hydrological years differed noticeably in sediment deposition as well, but in a distinct manner than they did in either rainfall or streamflow (Table 1). The second, driest year deposited the largest amount of sediment per day $(3.7 \mathrm{~kg})$, i.e. 1.6 times more than the third, wettest year, and 1.3 times more than the first, "average" year. Consequently, these between-year differences in deposition were more pronounced when expressed per mm of rainfall (3.7 and 1.6 times). Likewise, the differences in deposition per mm of streamflow were more striking (2.9 and 1.8 times).

The granulometric composition and organic matter content of the deposited sediment were only determined for one complete hydrological year, i.e. the first one. While the fine earth fraction $(<2 \mathrm{~mm})$ out-weighted the stone fraction by a factor four ( $81 \mathrm{vs} .19 \%)$, the two fractions themselves were dominated by the size classes of $0.2-<1 \mathrm{~mm}(72 \%)$ and $>5 \mathrm{~mm}(62 \%)$, respectively. The organic matter content of the fine earth fraction amounted to $5 \%$. 


\subsection{Overall sediment deposition before and after bench terracing}

Daily sediment deposition was some $30 \%$ higher over the roughly 5-month period before the bench terracing than over the remaining study period, amounting to 3.8 and $2.8 \mathrm{~kg} \mathrm{day}^{-1}$, respectively (Table 2 ). Sediment deposition per mm of rainfall, however, was $30 \%$ smaller for the pre- than post-terracing period. Furthermore, sediment deposition per $\mathrm{mm}$ of streamflow was basically the same for both periods.

Table 2. Within-flume sediment deposition on a daily basis and per mm of rainfall and streamflow in a recently burnt forest catchment before and after bench terracing.

\begin{tabular}{|c|c|c|c|c|c|}
\hline \multirow[b]{2}{*}{ Period } & \multirow[b]{2}{*}{$\begin{array}{c}\text { Start date } \\
(\text { dd-mm-yy) }\end{array}$} & \multirow[b]{2}{*}{$\begin{array}{c}\mathrm{Nr} \\
\text { of days }\end{array}$} & \multicolumn{3}{|c|}{ Sediment depositions } \\
\hline & & & $\begin{array}{l}\text { per day } \\
\left(\text { kg day }^{-1}\right)\end{array}$ & $\underset{\left(\mathrm{kg} \mathrm{mm}^{-1}\right)}{\text { per mm of rainfall }}$ & $\begin{array}{c}\text { per mm of } \\
\text { streamflow } \\
\left(\mathrm{kg} \mathrm{mm}^{-1}\right)\end{array}$ \\
\hline Pre-terracing & $05-10-10$ & 156 & 3.8 & 0.5 & 0.8 \\
\hline Post-terracing & $10-03-11$ & 939 & 2.8 & 0.7 & 0.8 \\
\hline
\end{tabular}

These contrasting differences in deposition per day and per $\mathrm{mm}$ of rainfall/ streamflow could be an artefact, reflecting the confounding effect of the much shorter duration of the pre- than post-terracing period, in particular as rainfall in the study region has a marked seasonal pattern. The October-March period of the 2011/12 hydrological year, however, was much drier than the 2010/11 October-March period, with twice as little rainfall (565 vs. $1128 \mathrm{~mm}$ ). Therefore, the 2011/12 period was extended till the end of June 2012 to be comparable with the pre-terracing period in terms of both total rainfall and total streamflow volumes ( 6 and $+4 \%$, respectively). This October-June 2011/12 period revealed consistently higher deposition figures than the pre-terracing period. Daily deposition was some $10 \%$ higher, while deposition per mm of rainfall and streamflow were about 2 times higher.

The sediment deposited over the pre-terracing period was somewhat coarser than that deposited over the first hydrological year as a whole, with the $>2 \mathrm{~mm}$ fraction amounting to $28 \%$ as opposed to $19 \%$. The same tendency for less coarse material being deposited after than before bench terracing was also suggested by the sediment deposited over the October-March period of the 2011/12 hydrological year. Its $>2 \mathrm{~mm}$ fraction equalled just $12 \%$ and this fraction consisted for more than $50 \%$ of elements $\leq 5 \mathrm{~mm}$.

\subsection{Temporal patterns in sediment deposition}

Daily sediment deposition of the 101 individual read-outs varied markedly throughout the study period, ranging from 0.2 to $47.4 \mathrm{~kg} \mathrm{day}^{-1}$ (Fig. 2). This maximum value occurred more than one year after the terracing, during early May 2012, at the end of a 7-day period with a relatively high daily rainfall volume (26 $\left.\mathrm{mm} \mathrm{day}^{-1}\right)$ as well as a relatively high maximum rainfall intensity $\left(\mathrm{I} 30=23 \mathrm{~mm} \mathrm{~h}^{-1}\right)$. It was immediately followed by the third highest sedimentation peak in the time series $\left(17.7 \mathrm{~kg} \mathrm{day}^{-1}\right)$, which, by contrast, had accumulated over a 7-day period without any rainfall. Together, 
these two periods were responsible for about one third of the sediment deposited over the second hydrological year as a whole.
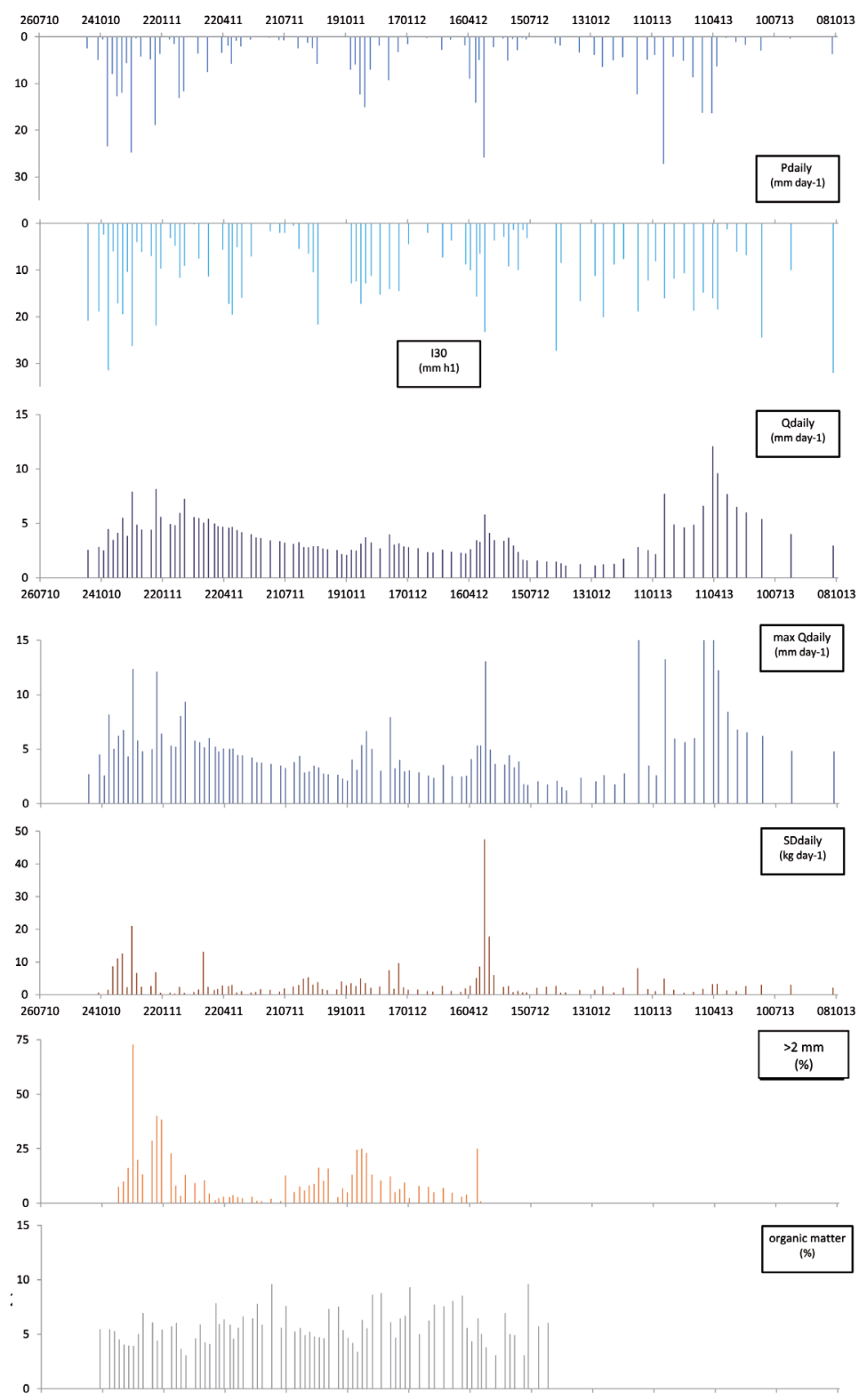

Figure 2. Temporal patterns of daily rainfall volume (Pdaily), maximum rainfall intensity (I30), average and maximum streamflow volumes (Qdaily and max Qdaily, respectively), daily sediment deposition (SDdaily), and the contents of coarse elements $(>2 \mathrm{~mm}$ ) and organic matter of the deposited sediments for the individual read-outs during the first three years after a wildfire. 
From the remaining four sedimentation peaks that exceeded $10 \mathrm{~kg} \mathrm{day}^{-1}$, three occurred during the pre-terracing phase, taking place almost consecutively between midNovember and early December 2010. While these three peaks together corresponded to around half of the sediment deposited over the entire pre-terracing phase, the third of these peaks involved roughly twice as much sediment deposition on a daily basis as the two preceding peaks (21.0 vs. 11.0-2.5 kg day-1). This third peak also stood out for its comparatively large fraction of coarse elements $(>2 \mathrm{~mm})$, amounting to $73 \%$ of the total deposited sediment as opposed to $7-10 \%$ in the case of the other two peaks. The same was true in relation to all pre-terracing read-outs (0-40\%) and all post-terracing readouts (1-25\%). This third pre-terracing peak furthermore corresponded to a clearly rainier period than the two preceding peaks, as its daily rainfall volume was about twice as high ( 25 vs. $12-13 \mathrm{~mm} \mathrm{day}^{-1}$ ) and its maximum rainfall intensity some $35-50 \%$ higher (I30: 26 vs. $\left.17-19 \mathrm{~mm} \mathrm{~h}^{-1}\right)$.

The fourth remaining sedimentation peak that exceeded $10 \mathrm{~kg}^{\text {day }}{ }^{-1}$ occurred during mid-March, i.e. immediately after the start of the terracing (Fig. 2). Like in the case of the second highest sedimentation peak, it was recorded at the end of a period without any rainfall; unlike in the case of this second highest peak, however, it was not preceded by a read-out with an important sediment deposition and/or with an elevated rainfall volume and maximum intensity.

The results of the runs test above and below the median did not reveal or even hint at that daily sediment deposition in this study differed significantly from a random pattern. This was not only true for the 101 read-outs making up the entire study period (number of runs $=32 ;|Z|=0.76$ ) but also for the 83 read-outs constituting the postterracing period (number of runs $=28 ;|Z|=0.69$ ). Furthermore, the results of the run test were, in essence, the same for sediment deposition per $\mathrm{mm}$ of rainfall $(\mathrm{IZI}=0.15$ and $0.35)$ as for sediment deposition per mm of streamflow $(\mathrm{IZI}=0.81$ and 0.84$)$.

\subsection{Relations of sediment deposition with rainfall and streamflow}

Daily sediment deposition of the individual read-outs was related with rainfall as well as with streamflow in an exploratory manner, computing Pearson's correlation coefficient (r) for various (overlapping) data sets and, in several cases, eliminating possible outliers based on visual inspection of scatter plots. Therefore, the coefficients' statistical significance as indicated in table 3 must be interpreted with due caution.

Daily sediment deposition over the entire study period was more strongly related with daily rainfall volume than with maximum rainfall intensity or with average and maximum daily streamflow volume (Table $3: r=0.50$ vs. $0.23-0.38$ ). These four coefficients tended to be clearly lower when sediment deposition was expressed per $\mathrm{mm}$ of rainfall $(|0.01-0.30|)$ or per mm of streamflow (I0.09-0.31I), so that further analysis was limited to the daily figures.

The correlation of daily sediment deposition with the two rainfall and two streamflow variables tended to be stronger over the individual hydrological years than over the study period as a whole (Table 3). The respective differences in correlation coefficients were 
most pronounced in the instance of the second hydrological year as well as in the case of the correlation with the maximum daily streamflow volume. Hence, daily sediment deposition was clearly more closely associated with maximum daily streamflow volume than with daily rainfall volume during the hydrological years of 2011/12 (0.82 vs. 0.67) and $2012 / 13$ (0.59 vs 0.49 ), while it was about equally correlated with both variables during the first hydrological year (0.53 and 0.49 ). The plots of daily sediment deposition against both daily rainfall volume and maximum daily streamflow volume suggested clear differences between the three hydrological years (Fig. 3). Sediment deposition appeared to increase more strongly with increasing rainfall/streamflow during the second than the first and third years.

Table 3. Pearson's correlation coefficients of daily sediment deposition $\left(\mathrm{kg} \mathrm{day}^{-1}\right)$ of the individual read-outs with daily rainfall volume, maximum rainfall intensity (I30), and average and maximum daily streamflow volume for different study periods (i.e. entire study and 3 hydrological years).

\begin{tabular}{|c|c|c|c|c|}
\hline Period & $\begin{array}{c}\text { Daily rainfall } \\
\text { volume } \\
\left(\mathbf{m m} \text { day }^{-1}\right)\end{array}$ & $\begin{array}{c}\text { Maximum } \\
\text { rainfall intensity } \\
\left(\mathrm{mm} \mathrm{h}^{-1}\right)\end{array}$ & $\begin{array}{l}\text { Average daily } \\
\text { streamflow volume } \\
\left(\mathrm{mm} \text { day }^{-1}\right)\end{array}$ & $\begin{array}{l}\text { Maximum daily } \\
\text { streamflow volume } \\
\left(\mathbf{m m} \text { day }^{-1}\right)\end{array}$ \\
\hline entire study & 0.50 & 0.28 & 0.23 & 0.38 \\
\hline 2010/11 & 0.53 & 0.37 & 0.37 & 0.49 \\
\hline $2011 / 12$ & 0.67 & 0.38 & 0.71 & 0.82 \\
\hline $2012 / 13$ & 0.49 & 0.35 & 0.16 & 0.58 \\
\hline
\end{tabular}
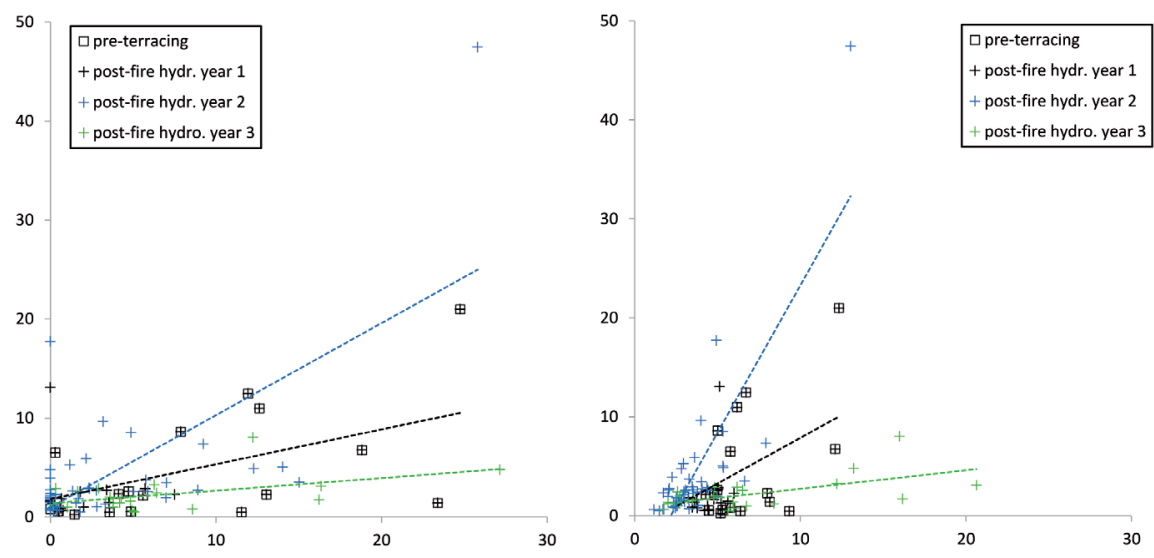

Figure 3. Relationship of daily sediment deposition with daily rainfall (left) and maximum daily streamflow (right), showing the values of the individual read-outs for four different study periods as well as the corresponding trend lines. 
As was easily perceived from Fig. 3, the correlation coefficients of daily sediment deposition with daily rainfall volume could be markedly improved in the instances of the 2010/11 and 2011/12 hydrological years (to 0.62 and 0.74 ) by eliminating two of the sedimentation peaks of more than $10 \mathrm{~kg} \mathrm{day}^{-1}$. Namely, the two peaks that involved no rainfall might be regarded as potential outliers. The 2010/11 coefficient could be increased even further (to 0.74 ) when ignoring the first post-fire read-out combining a large rainfall volume $\left(23 \mathrm{~mm} \mathrm{day}^{-1}\right)$ with a high rainfall intensity $\left(\mathrm{I} 30=34 \mathrm{~mm} \mathrm{~h}^{-1}\right)$. This read-out at the start of November 2010 involved little sediment deposition, for example in comparison to the subsequent read-out that involved roughly 6 times more sediment deposition with 4 times less rainfall at a 5 times lower intensity. As a final note, the 2010/11 coefficient of 0.74 was strongly influenced by the largest peak in daily sediment deposition during early May 2012 - removing this read-out dropped the coefficient's value to 0.46 . On the other hand, eliminating this read-out did not alter the abovementioned tendency for sediment deposition at a certain rainfall/streamflow volume to be higher during the second than third hydrological year.

\section{Discussion}

\subsection{Comparison of sediment deposition with plot-scale soil erosion}

The observed within-flume sediment deposition rates were used to compute catchment-scale sediment yields (or, to be more precise, minimum estimates thereof) for the two periods for which Martins et al. (2013) presented plot-scale sediment losses for two slopes within the same study catchment. In the case of the pre-terracing phase, total sediment yield was $20.6 \mathrm{~kg} \mathrm{ha}^{-1}$ (assuming no export before 4 October 2010), while plot-scale sediment losses were, in median, around 8.5 times higher at a maritime pine plantation and about 12 times higher at an eucalypt plantation. In the case of the first 18 months of the post-terracing phase, total sediment yield amounted to $59.2 \mathrm{~kg} \mathrm{ha}^{-1}$, and was roughly 200 and 600 times smaller than the plot-scale sediment losses at the pine and eucalypt site, respectively.

This important terracing-associated change in sediment delivery ratio from 8-11 to $0.2-0.5 \%$ could be explained first and foremost by the fact that while the pre-terracing sediment losses of Martins et al. (2013) concerned regular slope parts, their postterracing losses concerned recently constructed trails. The authors estimated that trail construction increased plot-scale sediment losses by more than an order of a magnitude (from 0.9 to $12.1 \mathrm{Mg} \mathrm{ha}^{-1}$ ). Martins et al. (2013) also argued that since such trails only constituted a minor part of the terraced area, their post-terracing sediment losses could not be scaled-up directly. Furthermore, while extensive rill formation was observed in one of the two trails studied by Martins et al. (2013), it was not a common feature throughout the terraced study catchment. Even so, just by extending the network of trails, terracing can be expected to have increased the hydrological connectivity that is provided by the trail network. This could counteract the expected, overall reduction in connectivity at the catchment-scale, through the interruption by the terraces of the across-slope fluxes (Arnáez et al., 2015). Monitoring of the water and sediment fluxes 
across the trail network was beyond the scope of this study but would seem an important, albeit challenging topic for further research in recently terraced forest plantations.

Possibly, the pre-terracing sediment delivery ratio was somewhat under-estimated by the comparatively low plot-scale sediment losses in Martins et al. (2013), which on an annual basis were estimated to be $0.5-0.6 \mathrm{Mg} \mathrm{ha}^{-1} \mathrm{yr}^{-1}$ in the case of the maritime pine plantation, and $0.7-0.8 \mathrm{Mg} \mathrm{ha}^{-1} \mathrm{y}^{-1}$ in the case of the eucalypt plantation. Other plot-based studies in central Portugal found markedly higher erosion rates for recently burnt maritime pine and eucalypt plantations. For example, Prats et al. (2013) reported sediment losses of 3-4 Mg ha-1 $\mathrm{yr}^{-1}$ for a pine plantation during the first two years after fire, while Prats et al. (2014b) measured losses of 8-9 $\mathrm{Mg} \mathrm{ha}^{-1} \mathrm{yr}^{-1}$ for a eucalypt plantation during the first year after fire.

The above-mentioned pre- and post-terracing sediment delivery ratios could furthermore be somewhat under-estimated due to the small size of the plots used by Martins et al. (2013: c. $\left.0.28 \mathrm{~m}^{2}\right)$. Nonetheless, Prats et al. $(2013,2014 \mathrm{~b})$ used the same micro-plots. Furthermore, Prats et al. (2013) found no obvious differences between the sediment losses of their micro-plots and of their plots of $10 \mathrm{~m}^{2}$.

\subsection{Comparison of sediment deposition with catchment-scale sediment yields}

The estimates of sediment yield obtained in this study were difficult to appreciate through a comparison with literature, as surprisingly few studies seem to have monitored post-fire sediment yield for Mediterranean catchments (see Shakesby, 2011). Furthermore, the three studies included in the review by Shakesby (2011) presented contrasting figures. Inbar et al. (1998) reported a sediment yield of $0.036 \mathrm{Mg} \mathrm{ha}^{-1} \mathrm{yr}^{-1}$ for the first year after fire, which is identical to the total amount of sediments deposited over the first post-fire hydrological year of the present study $\left(0.037 \mathrm{Mg} \mathrm{ha}^{-1} \mathrm{yr}^{-1}\right)$. By contrast, Mayor et al. (2007) and Lavabre and Martin (1997) observed post-fire sediment yields that were two orders of magnitude higher, the former study during the third year after fire (3.7 $\mathrm{Mg} \mathrm{ha}^{-1} \mathrm{yr}^{-1}$ ) and the latter during the first year (5.7 $\left.\mathrm{Mg} \mathrm{ha}^{-1} \mathrm{yr}^{-1}\right)$. Besides, various other factors such as fire severity, post-fire rainfall regime, physiography of the terrain or soil erodibility, catchment size could play a confounding role in the comparison of the existing studies. With 2.7 ha, the catchment of Mayor et al. (2007) was more than 10 times smaller than the present one, and 50-70 times smaller than those of Inbar et al. (1988: $1.1 \mathrm{~km}^{2}$ ) and Lavabre and Martin (1997: $\left.1.5 \mathrm{~km}^{2}\right)$.

The present estimates of sediment yield should be considered minimum estimates for two reasons. They not only ignored the sediments that were exported in suspension (which is topic of ongoing analysis) but also disregarded the sediments that were retained by two retention ponds in the upstream channel network. Apparently, these ponds had been used for irrigating some small and dispersed agricultural fields located near the stream and for controlling the discharge for a water mill at the catchment outlet, but the ponds as well as the fields and water mill had been abandoned by the time of the wildfire and, most probably, quite some time before. The two ponds were "equipped" with 10/12 rebars of $1.5 \mathrm{~m}$ long on 22 September 2010, placed in a grid of two rows of 5/6 rebars 
across the width of the pond area. About one year later, by 14 September 2011, sediment deposition had attained an average thickness of $76 \mathrm{~cm}$ in the upper pond and $28 \mathrm{~cm}$ in the lower pond. The corresponding sediment volumes amounted to roughly 14 and $2.5 \mathrm{~m}^{3}$, respectively, while the respective sediment loads were estimated to be at least 6.5 and $1.2 \mathrm{Mg}$ (i.e. assuming a moisture content of $40 \%$, which is well above the overall average of $33 \%$ of the deposited sediments, and assuming a dry bulk density of $0.78 \mathrm{Mg} \mathrm{m}^{3}$, the lower range in Verstraeten and Poesen (2001)). These figures would raise the sediment yield over the first post-fire hydrological year by almost a factor 8.5 , to $0.312 \mathrm{Mg} \mathrm{ha}^{-1} \mathrm{yr}^{-1}$, but would leave it much -roughly one order of a magnitude- lower than the values presented by Mayor et al. (2007) and Lavabre and Martin (1997).

The retention of sediments by these two ponds also seemed to offer a plausible justification for considering the first major rainfall read-out following the wildfire (early November 2010) as a possible outlier in the relation of daily sediment deposition with daily rainfall volume. At the same time, these retained sediments could be an important source of the sediments that were being deposited during the periods without any rainfall or with little and/or less intense rainfall. Possibly, however, the rainless peak in sediment deposition of mid-March 2001 was directly related to the bench terracing operations themselves, including by the fact that various uprooted eucalypt trunks (with considerable amounts of soil attached to them) ended up near or in the channel network.

The important role of the retention ponds in the catchment erosion response was also suggested by the organic matter contents of the sediments deposited in the flume. During the pre-terracing phase, these contents varied between 3 and $7 \%$ and were much lower than the contents observed by plot-scale erosion studies in the region. For example, Prats et al. $(2013,2014 \mathrm{~b})$ reported average organic matter contents of 50-60\% in sediments eroded during the first one to two years after fire, while Malvar et al. (2013) obtained somewhat lower figures of (16-)30-40-(47)\% under simulated rainfall. Worth noting was furthermore that the soils studied by Prats et al. (2013, 2014b) and Malvar et al. (2013) typically contained $10-11 \%$ of organic matter in their upper $5 \mathrm{~cm}$. During the post-terracing phase, the organic matter contents of the deposited sediments remained basically unchanged, amounting on average to $6 \%$ as opposed to $5 \%$. This could indicate that the bulk of the sediment deposited before and after terracing came from the same source and, in particular, from the two retention ponds rather than from the recently burnt or recently terraced hillslopes. Nonetheless, the recently terraced hillslopes could not be all together excluded as a possible source of the deposited sediments, as the topsoil organic matter content following terracing was not extensively studied. Even so, the few available data suggested contents in the range of 1-3\% up to two years after the terracing (Razzetto, 2013) and, thus, below the contents of the deposited sediments.

\section{Conclusions}

The main conclusions of this study into the deposition of sediments in a flume at the outlet of a forest catchment following a wildfire and, some six months later, bench terracing by bulldozer were the following: 
(i) relatively small amounts of sediment were deposited over all three hydrological years, not only in comparison with the -admittedly, very few- published post-fire sediment yields in Mediterranean catchments but also in comparison with the plotscale sediment losses within the catchment as well as with the estimated deposition in upstream retention ponds;

(ii) sediment deposition appeared to be greater before than after bench terracing but the difference was relatively minor, especially when compared with the contrast in plotscale sediment losses before and after terracing;

(iii) individual read-outs contributed in a substantial manner to annual amounts of deposited sediments;

(iv) daily sediment deposition was reasonably well related to daily rainfall volume over the study period as a whole, but tended to better related to maximum daily streamflow over the individual hydrological years, including the observed lagging-behind;

(v) these linear relations, however, did not fully capture the complex nature of sediment deposition as, for example, evidenced by two important peaks at the end of rainless periods.

\section{Acknowledgements}

The present study was carried out in the framework of the FIRECNUTS project (PTDC/AGRCFL/104559/2008), funded by the FCT/MCTES (PIDDAC), with co-funding by FEDER through COMPETE (Programa Operacional Factores de Competitividade; POFC), and with support of the research grants, attributed by FCT/MCTES, of SPA (SFRH/BD/ 33392/2008), DS (SFRH/BPD/92650/2013), SRF (SFRH/BD/75562/2010), METV (SFRH/BPD/63808/ 2009) and MERR (SFRH/BPD/64425/2009). Additional financial support was provided by the FCT/MCTES/FEDER-funded project RESORT (PTDC/CTE-ATM/111508/2009) and the EU-FP7 project RECARE (contract number grant agreement 603498). We further gratefully acknowledge the help of various other colleagues of the ESP team and, in particular, Robbert de Lenne and Ton van der Linden with field data and sample collection and/or with laboratory analysis of the sediment samples. Finally, we want to thank the two anonymous reviewers for their comments and suggestions, which have been most useful to improve the original version.

\section{References}

APHA (American Public Health Association) 1998. Total suspended solids dried at 105 degrees Celsius method 2540D. In Standard Methods for the Examination of Water and Waste Water, 20th ed., Washington, DC, USA.

Arnáez, J., Lana-Renault, N., Lasanta, T., Ruiz-Flaño, P., Castroviejo, J. 2015. Effects of farming terraces on hydrological and geomorphological processes. A review. Catena 128, 122-134.

Bodí, M., Cerdà, A., Mataix-Solera, Doerr, S. H. 2012. Efectos de los incendios forestales en la vegetación y en el suelo de la cuenca mediterránea: revisión. Boletín AGE 58, 33-55. 
Cardoso, J.C., Bessa, M.T., Marado, M.B. 1971. Carta dos solos de Portugal (1:1,000,000). Serviço de Reconhecimento e de Ordenamento Agrário, Secretaria de Estado da Agricultura, Lisbon, Portugal.

Cardoso, J.C., Bessa, M.T., Marado, M.B. 1973. Carta dos solos de Portugal (1:1,000,000). Agronomia Lusitana 33, 461-602.

Cerdà, A. 1998. Changes in overland flow and infiltration after a rangeland fire in a Mediterranean shrubland. Hydrological Processes 12, 1031-1042.

Cerdà, A., Bodí, M.D. 2007. Erosión hídrica en suelos afectados por incendios forestales. In: Mataix-Solera, J. (ed.): Incendios forestales, suelos y erosión hídrica, CEMACAM, Font Roja-Alcoi, pp. 71-118.

Cerdà, A., Doerr, S.H. 2008. The effect of ash and needle cover on surface runoff and erosion in the immediate post-fire period. Catena 74, 256-263.

DRA-Centro (Direcção Regional do Ambiente do Centro) 1998. Plano de bacia hidrográfica do Rio Vouga, $1^{a}$ fase, Análise e diagnóstico da situação de referência, Análise biofísica. Anexos. Lisboa, Portugal.

DUDF (Direcção de Unidade de Defesa da Floresta) 2011. Relatório Anual de Áreas Ardidas e Ocorrências 2010. Autoridade Florestal Nacional, Lisboa.

Fernandéz-Raga, M., Fraile, R., Keizer, J.J., Varela, M.E.T., Castro, A., Palencia, C., Calvo, A.I., Koenders, J., Marques, R.L.C. 2010. The kinetic energy of rain measured with an optical disdrometer: An application to splash erosion. Atmospheric Research 96, 210-240.

Ferreira, A. de B. 1978. Planaltos e montanhas do norte da Beira - estudo de geomorfologia. Centro de Estudos Geográficos, Lisbon, Portugal.

Ferreira, A.J.D., Coelho, C.O.A., Ritsema, C.J., Boulet, A.K., Keizer, J.J., 2008. Soil and water degradation processes in burned areas: lessons learned from a nested approach. Catena 74, 273-85.

Inbar, M., Tamir, M., Wittenberg, L. 1998. Runoff and erosion processes after a forest fire in Mount Carmel, a Mediterranean area. Geomorphology 24, 17-33.

Keeley, J.E. 2009. Fire intensity, fire severity and burn severity: A brief review and suggested usage. International Journal of Wildland Fire 18 (1), 116-126.

Lavabre, J., Martin, C. 1997. Impact d'un incendie de forêt sur l'hydrologie et l'érosion hydrique d'un petit bassin versant méditerranéan. Human Impact on Erosion and Sedimentation (Proceedings of Rabat Symposium S6, April 1997). IAHS Publication 245, 39-47.

Leighton-Boyce, G., Doerr, S.H., Shakesby, R.A., Walsh, R.P.D. 2007. Quantifying the impact of soil water repellency on overland flow generation and erosion: a new approach using rainfall simulation and wetting agent on in situ soil. Hydrological Processes 21, 2337-2345.

Malvar, M.C., Prats, S.A., Nunes, J.P., Keizer, J.J. 2011. Post-fire overland flow generation and inter-rill erosion under simulated rainfall in two eucalypt stands in north-central Portugal. Environmental Research 111, 222-236.

Malvar, M.C., Martins, M.A.S., Nunes, J.P., Robichaud, P.R., Keizer, J.J. 2013. Assessing the role of pre-fire ground preparation operations and soil water repellency in post-fire runoff and inter-rill erosion by repeated rainfall simulation experiments in Portuguese eucalypt plantations. Catena 108, 69-83.

Martins, M.A.S., Machado, A. I., Serpa, D., Prats, S.A., Faria, S.R., Varela, M.E.T., GonzalezPelayo O., Keizer J.J. 2013. Runoff and inter-rill erosion in a Maritime Pine and a eucalypt plantation following wildfire and terracing in north-central Portugal. Journal of Hydrology and Hydromechanics 61 (4), 261-269.

Mataix-Solera, J., Cerdà, A., Arcenegui, V., Jordán, A., Zavala, L.M. 2011. Fire effects on soil aggregation: a review. Earth-Science Reviews 109, 44-60. 
Mayor, A.G., Bautista, S., Llovet, J., Bellot, J. 2007. Post-fire hydrological and erosional responses of a Mediterranean landscape: seven years of catchment-scale dynamics. Catena 71, 68-75.

Morgan, R.P.C. 2005. Soil erosion and conservation. Blackwell Publishing Ltd., Bodmin.

Pereira, J.M.C., Carreiras, J.M.B., Silva, J.M.N., Vasconcelos, M.J. 2006. Alguns conceitos básicos sobre os fogos rurais em Portugal. In Incêndios Florestais em Portugal: Caracterização, Impactes e Prevenção, J.S. Pereira, J.M.C. Pereira, F.C. Rego, J.M.N. Silva, T.P. Silva (Eds.), ISAPress, Lisboa, pp. 133-161.

Prats, S.A., Malvar, M.C., Vieira, D.C.S, MacDonald L.H., Keizer J.J. 2013 (in press). Effectiveness of hydro-mulching to reduce runoff and erosion in a recently burnt pine plantation in central Portugal. Land Degradation \& Development, doi: 10.1002/ldr.2236.

Prats, S.A., Malvar, M.C., Martins, M.A.S., Keizer, J.J. 2014a. Post-fire erosion risk assessment and mitigation: new approaches for reducing runoff and soil erosion in Portugal. Cuadernos de Investigación Geográfica 40 (2), 403-427.

Prats, S.A., Martins, M.A.S., Malvar, M.C., Ben-Hur, M., Keizer, J.J. 2014b. Polyacrylamide application versus forest residue mulching for reducing post-fire runoff and soil erosion. Science of the Total Environment 468-469, 464-474.

Razzetto, G.F. 2013. Impacts of terracing after wildfires on soil water and matter budgets under eucalypt plantations following an artificial terracing time series. MSc thesis, Technical University of Dresden, Germany.

Shakesby, R.A. 2011. Post-wildfire soil erosion in the Mediterranean: Review and future research directions. Earth-Science Reviews 105, 71-100.

Shakesby, R.A., Doerr, S.H. 2006.Wildfire as a hydrological and geomorphological agent. EarthScience Reviews 74, 269-307.

Shakesby, R.A., Boakes, D.J., Coelho, C.O.A., Gonçalves, A.J.B., Walsh, R.P.D., 1996. Limiting the soil degradational impacts of wildfire in pine and eucalyptus forests, Portugal: comparison of alternative post-fire management practices. Applied Geography 16, 337-356.

SNIRH (Serviço Nacional de Informação dos Recursos Hídricos) 2011. On-line hydrometeorological data base (http://www.snirh.pt; accesses December 2011).

Sokal, R.R., Rohlf, F.J. 1981. Biometryseconded. W.H.Freeman and Company, New York, USA.

Terry, J.P., 1996. Erosion pavement formation and slope process interactions in commercial forest plantations, northern Portugal. Zeitschrift für Geomorphologie 40, 97-115.

Varela, M.E., Benito, E., Keizer, J.J. 2010. Wildfire effects on soil erodibility of woodlands in NW Spain. Land Degradation and Development 21, 75-82.

Verstraeten, G., Poesen, J. 2001. Variability of dry sediment bulk density between and within retention ponds and its impact on the calculation of sediment yields. Earth Surface Processes and Landforms 26, 375-394.

WRB 2006. World reference base for soil resources 2006. World Soil Resources Reports, 103. FAO, Rome. 